El reality-show de Ronald Reagan es el monstruo: They live de John Carpenter

Victoria Julia Lencina

Question, Vol. 1, N. 62, e162, abril-junio 2019

ISSN 1669-6581 | https://doi.org/10.24215/16696581e162

http://perio.unlp.edu.ar/ojs/index.php/question

FPyCS | Universidad Nacional de La Plata

La Plata | Buenos Aires | Argentina

\title{
El reality-show de Ronald Reagan es el monstruo: They live de John Carpenter
}

The Ronald Reagan reality-show is the monster: Carpenter's They live

\author{
Victoria Julia Lencina lencina.victoria@gmail.com \\ https://orcid.org/0000-0003-4331-9858
}

Centro de Investigación y Nuevos Estudios sobre Cine; Instituto de Historia del

Arte Argentino y Latinoamericano "Luis Ordaz"; Facultad de Filosofía y Letras;

Universidad de Buenos Aires (Argentina)

\section{Resumen}

Cualquier análisis histórico-político que intente realizarse sobre Estados Unidos en la década del ochenta encontrará su punta de lanza en el cine. La formación actoral de Ronald Reagan definió claramente su modo de hacer política. Su ideología, configurada mediante la lógica de las imágenes, resultó ser un auténtico reality show en el que gran parte del pueblo 
norteamericano, convertido en público, permanecía hipnotizado viendo sus discursos políticos mediante la pantalla televisiva. Recientemente, se han cumplido treinta años del estreno de They live (John Carpenter, 1988), una película de terror que retoma la estética panfletaria del gobierno de Regan para cuestionarla, parodiarla y criticarla. Un análisis de los aspectos narrativos del filme nos permitirá sostener que la construcción del monstruo (el cual asemeja un ser humano, pero presenta características alienígenas) y la configuración de un universo paralelo desconocido representan el proceso de transformación de la realidad que Reagan privilegiaba.

Palabras clave: Monstruo; Ronald Reagan; reality-show; ideología.

\section{Abstract}

Any historical-political análisis that attempts to be made on the United States in the decade of ' 80 will find its spearhead in the cinema. Ronald Reagan's acting training clearly defined his way of doing politics. Its ideology, configured by the logic of the images, turned out to be an authentic reality show in which a large portion of the American people, turned into public, remained hypnotized watching their political speeches through the televisión screen. 2018 marked the 30 aniversary of the premiere of They live (John Carpenter, 1988), a horror film that retakes the aesthetics of Regan's government to question, parody and criticize it. An analysis of the narrative aspects of the film will allow us to argue that the construction of themonster (which looks like a human being, but presents alien characteristics) and the configuration of an unknown parallel universe represent the process of transforming reality that Reagan made privileged.

Keywords: Monster; Ronald Reagan; reality-show; ideology.

La alteración del statu quo que provoca la aparición de un monstruo -alguien o algo que proviene de una realidad desconocida- constituye una de las fórmulas narrativas más antiguas y explotadas por el cine de terror. El diseño del monstruo se organiza en oposición a los valores que la cultura "blanca" occidental realza, tales como pureza, feminidad, castidad, inocencia y/o abstinencia. La caracterización espeluznante que adquiere se debe, en parte, a que es considerado una "otredad" que excede los límites morales impuestos por el sistema hegemónico. La contienda entre el bien y el mal se articula simbólicamente, en la gran mayoría de los casos, entre el hombre (blanco, cristiano, heterosexual, capitalista y burgués) y la otredad (lo abyecto). Este sistema binario ampara fuerzas en aparente oposición tales como la 
civilización y la barbarie, el orden y el caos, lo sagrado y lo profano. En este sentido, el monstruo encarna aquello que se reprime y representa todo lo que no se permite ni se acepta socialmente. Por tanto, el Otro simboliza un peligro al que estamos condicionados a repudiar, subyugar, transformar y/o aniquilar.

En el cine de ciencia ficción se introduce una temática similar. El tratamiento mítico de las ansiedades y angustias del presente posibilita la configuración de imaginarios sociales. Películas como The thing from another world (Christian Nyby, 1951); It came from outer space (Jack Arnold, 1953) e Invasion of the body snatchers (Don Siegel, 1956) "resultaron una plataforma ideológica efectiva para alimentar la discriminación, exaltar los valores patrióticos, denunciar las tretas del enemigo y asentar las excelencias del sistema político y social norteamericano" (La Torre, 1994: 5). En ambos géneros, se ponen en juego las identidades sociales.

En la tradición discursiva de estos géneros, sin embargo, se distingue un caso paradigmático, cuya propuesta se dirige a invertir el sistema de valores comúnmente utilizados para delinear a las figuras del bien y del mal. They live de John Carpenter, estrenada en 1988 -mismo año del cierre presidencial de Ronald Reagan-, retoma elementos de la ciencia ficción con el propósito de reelaborar la forma convencional del monstruo. A su vez, en el corazón de este trabajo, se encuentra una premisa central: la certeza de que el gobierno de Reagan dejó una serie de consecuencias sociales devastadoras para Estados Unidos, incluyendo un dinamismo de la propaganda capitalista, un alza del desempleo y del fenómeno de homeless. Esta problematización está en consonancia con la revisión a la que es sometido el concepto de "monstruo" en la película de Carpenter. Teniendo en cuenta este marco contextual, el trabajo se ocupará de analizar los efectos políticos de la resignificación narrativa de la otredad, que propone They live, en términos de materialización concreta del statu quo. En tren de indagar en esta cuestión realizaremos, en primera instancia, una aproximación teórica sobre los conceptos "terror" y "horror". Luego, abordaré las características del subgénero distopía y su vínculo con el cine de terror para examinar el tratamiento narrativo que va desarrollando el filme seleccionado. Por último, analizaré detalladamente los cambios suscitados por Carpenter sobre la figura del monstruo en comparación de la tradición narrativa del género de terror.

\section{Horror, terror y distopía}

Al comenzar la redacción de este artículo me debatí entre referirme a They live como una producción enmarcada dentro del cine de terror o hablar de ella en términos de ciencia ficción. 
Lo cierto es que el intento por clasificar a una película apelando a la noción de género conlleva dificultades insolubles de tipo práctico -deberíamos establecer los límites exactos del tipo genérico- y teórico -la reducción del concepto a un sentido clasificatorio traiciona sus desarrollos históricos- (Marzal, 1996; Altman, 1999). Por lo demás, la teoría de los géneros plantea el reconocimiento de una serie de recurrencias iconográficas, espaciales y narrativas que sólo pueden apreciarse en la singularidad de los textos.

Siguiendo el estudio de José Javier Marzal (1996), a veces nos encontramos con géneros con los que podemos vincular demasiados filmes a la vez que en algunas cintas cinematográficas podemos encontrar un entrecruzamiento de géneros. Basta pensar en el caso Invasion of the body snatchers (Don Siegel, 1956) que se estructura como un tradicional film noir aunque el tratamiento de la puesta en escena y la caracterización de personajes presenta varios puntos de contacto con el cine de ciencia ficción y el de terror. Lo mismo sucede en Alien (Ridley Scott, 1979) cuya historia es un auténtico relato de ciencia ficción mientras que ciertos elementos del decorado- por ejemplo, el interior de la nave -se corresponden con la estética gótica del cine de terror de los años 30. De este modo, la interacción de los géneros es constante y habitual en el universo cinematográfico, así como es estrecho el vínculo entre el terror y la ciencia ficción. Lo que subyace tras esa relación genérica se hace evidente con los conceptos de horror, otredad y monstruo.

La novelista británica Ann Radcliffe (1826), pionera de la novela gótica, plantea que terror y horror son conceptos opuestos; mientras el primero se ajusta al sentimiento experimentado por el sujeto ante un nivel de vida diferente, el segundo refiere al contenido narrativo que sugiere incertidumbre y malestar al localizar una historia en las profundidades de la oscuridad. Siguiendo esta línea de pensamiento, Margarita Cuéllar Barona, distingue que "el horror alude a lo monstruoso, lo vil, lo intangible, lo atroz, etcétera, mientras que el terror apunta hacia el sentimiento que sobrecoge cuando el miedo toma posesión del cuerpo impidiendo el pensamiento racional" (2008: 1). De este modo, proseguiremos por referirnos como "terror" a los sentimientos vivenciados por el espectador y por "horror" a la propuesta narrativa de la película.

En términos que competen al cine de terror y al de ciencia ficción observamos que las emociones que se generan -miedo, ansiedad, suspenso y angustia- están motivadas por el esquema binario: "bien versus mal". En dicho sistema la figura del monstruo juega un rol esencial debido a que su presencia es la que encarna los conflictos sociales. Tal como enuncia Robin Wood, dichos géneros revelan la historia de las ansiedades del siglo XX, donde el monstruo se ha convertido en el espacio donde se proyectan todos los malestares (Wood, 2002: 31). Para este autor, una definición básica del cine de horror podría resumirse como una 
serie de producciones donde "la 'normalidad' es amenazada por un monstruo" (Ídem). El orden simbólico queda organizado mediante la norma del hombre de raza blanca, cristiano, capitalista y burgués, siendo considerado como otredad todo lo que exceda esos valores.

Por su parte, Edward Guerrero argumenta que "la construcción social y las representaciones raciales, la otredad y lo no-blanco, son procesos en permanente evolución que se expresan de manera simbólica en el cine, en especial en las alegorías y metáforas presentes en el cine de ciencia ficción y en el cine de horror" (1993: 57). Guerrero señala que el monstruo se configura a partir de "las represiones políticas y sociales, al igual que de los miedos, los tabúes, las memorias y los temas que la sociedad se rehúsa a confrontar" (Ibídem: 43). Películas como Invasion of the body snatchers (Don Siegel, 1956) se nutren del temor a la otredad, Io desconocido y el imaginario que se crea, a finales de la Segunda Guerra Mundial en Estados Unidos, alrededor del comunismo. La película narra la historia de un médico cuyos pacientes se acercan con la inquietud de que sus familiares no son quienes dicen ser y que manifiestan una personalidad bastante extraña. Luego, a raíz de la aparición de un cadáver sin huellas dactilares, el médico descubre que el pequeño pueblo de Santa Mira es el epicentro de una invasión alienígena, donde los habitantes son sustituidos por réplicas que nacen de unas misteriosas vainas. La semilla aparece como alegoría de la rápida e incontrolable propagación de la ideología comunista en suelo norteamericano. El hombre occidental capitalista aparece como portador de valores puros y felices, mientras que el sorprendente ultraje a sus cuerpos queda en manos de una figura extraterrestre, sin sentimientos. El imaginario sobre el hombre comunista se nutre de la representación que se hace del nativo ruso donde se lo suele mostrar inquebrantable, semi máquina-humana y desprovisto de emociones (1).

La perpetua dependencia hacia la otredad que poseen tanto el género cinematográfico de horror y de ciencia ficción se revela en la mayoría de los materiales que producen. Películas como Video drome (David Cronenberg, 1983), por ejemplo, escenifican el temor por la alienación y el peligro que supone el consumo ilimitado de televisión, el video e internet. Es necesario señalar, que dentro del universo de la ciencia ficción se observa una interesante gama de subgéneros, tales como: utopía, eutopía, distopía, ucronía, entre otros. La distopía refiere a "una sociedad alternativa donde se niega algún valor muy importante en la concepción del autor, lo cual la hace decididamente indeseable. También puede ser una caricatura de la sociedad actual lograda mediante la extrapolación de algunas de sus tendencias y su reducción al absurdo" (Capanna, 1992: 132). Ejemplos de esta tendencia pueden ser Omicron (Ugo Gregoretti, 1963), que narra las andanzas de un invasor que quiere dominar a los poderosos para controlar a las masas, en una evidente sátira de la burguesía; o Fahrenheit 451 (François Truffaut, 1966) (2) que ficcionaliza sobre un cuerpo de bomberos -en nuestro lenguaje serían 
"antibomberos"- cuya misión es quemar libros en defensa de un orden social que, para ellos, constituye un mundo feliz que no debe ser alterado.

A lo largo de su historia, el cine de ciencia ficción resultó un efectivo vehículo para hacer crítica política y social. Ubicando la acción en el futuro, en otros planetas o involucrando seres provenientes de una realidad desconocida, como en las películas de marcianos de los 50, pareciera ser más sencillo realizar comentarios sobre determinado gobierno que en un contexto más cotidiano. Sin embargo, el universo que John Carpenter crea en They live es profundamente tangible para nosotros. En el filme, una señal de televisión se convierte en el órgano polifónico de una progresiva invasión mundial. Uno de los aspectos interesantes del largometraje es que los extraterrestres que aparecen no doblegan a las autoridades ni escapan de ella, sino que ellos mismos son las autoridades. De este modo, la ley, los medios masivos de comunicación y el estado forman parte de un sistema basado en el capitalismo más salvaje, que planea dominar a los humanos mediante una política alienante y de consumo. La distopía de horror, entonces, se revela en el modo que el capitalismo aglutina sus discursos de dominación y va adiestrando subjetividades.

Precisamente, la inversión de valores con los cuales se suele delinear al hombre y a la otredad constituye el gesto innovador de Carpenter dentro del género de terror. La reelaboración narrativa de los aspectos convencionales con los que se suele delinear al monstruo convierte al filme en un buen vehículo para la realización de una crítica social y política.

\section{El horror del planeta Reagan}

La década del ochenta para los Estados Unidos significó un regreso a los valores básicos del conservadurismo norteamericano: el patriotismo, la religiosidad, la familia y el arma. En 1981, por primera vez en la historia, el país veía la manera en que un actor de Hollywood se convertía en presidente. Ronald Reagan, que había liderado el Screen Actors Guild en defensa de valores anticomunistas en la industria del cine y, posteriormente, fuera gobernador de California por el Partido Republicano, ganó las elecciones a la presidencia con la mayoría absoluta en noviembre de 1980. La jornada electoral registró el porcentaje de participación más bajo en la historia del país (Jenkins, 2012).

Durante su mandato, que duraría hasta 1988, Reagan subrayó la necesidad de seguir los principios de la Asociación Nacional del Rifle: "la mejor defensa es el ataque (...) dispara antes de que te disparen" (Breixo Viejo: 18). Apoyó los regímenes conservadores de El Salvador y Honduras, y expresó su interés por financiar la guerrilla contrarrevolucionaria antisandinista de 
Nicaragua. Su acción bélica más directa fue la invasión de la isla de Granada. A nivel nacional, redujo el gasto público de los programas sociales y propugnó una moral regresiva convirtiendo en realidad la frase "opulencia privada, miseria pública". La política fiscal que emprendió causó un endeudamiento de casi cuatro billones de dólares al país y dio paso a las tasas de desempleo más altas de la segunda mitad del siglo XX y a una irremediable desaparición de las infraestructuras públicas.

Cualquier análisis histórico-político que intente realizarse sobre Estados Unidos en la década del ochenta encontrará su punta de lanza en el cine. La formación actoral de Reagan definió claramente su modo de hacer política. Su ideología se configuró mediante la lógica de las imágenes. Su gobierno resultó ser un auténtico reality show en el que gran parte del pueblo norteamericano, convertido en público, permanecía adormecido viendo sus discursos políticos mediante la pantalla televisiva. Al reflexionar sobre este período, el crítico de arte Robert Hughes declaró: "con la eficacia de un sonámbulo, [Reagan] educó a América hasta rebajarla a su nivel. Dejó a su país en 1988 un poco más estúpido que en 1980 y mucho más tolerante con las mentiras, porque su estilo de presentar las imágenes cortaba el vínculo entre las ideas y estimulaba la derrota del pensamiento" (1994: 53).

1988 fue el año del cierre presidencial de la era Reagan y fue también el año en que John Carpenter estrenó They live. Inspirada en el cuento "Eight O'clock in the Morning" ("Ocho de la mañana") (3) de Ray Nelson, la película narra la historia de John Nada, un obrero sin hogar, que tiene una revelación espeluznante sobre la realidad que le rodea. Este individuo descubre que la clase dominante es, en efecto, una raza de alienígenas que se hacen pasar por seres humanos. Estos extraterrestres, bajo la apariencia cotidiana de sus acciones y vestuario, manipulan a la humanidad para que obedezca al sistema, responda a las necesidades del consumismo capitalista y acepte el statu quo sin rebelarse. Sin lugar a dudas, el hecho de que Hollywood haya pasado a ser la realidad política de Estados Unidos, durante los 80, tuvo su repercusión en el mundo artístico. John Carpenter manifestó de forma muy explícita:

\begin{abstract}
América está estancada. Nuestros muchachos piensan que el Sol gira alrededor de la Tierra y la mitad no sabe ni leer (...) Y no exagero, lo único que hacen es mirar televisión. ¡Es deprimente! Estar contentos en los Estados Unidos consiste en tener un buen coche y en ir bien maquillado, entonces todo es perfecto. La filosofía de Reagan es el Capitalismo incontrolado. Reagan es una enfermedad, y los alienígenas de mi película son tan estúpidos como él (Orta, 2012: 80).
\end{abstract}

En el apartado anterior nos referimos a They live bajo la clasificación "distopía de horror" y profundizamos en la explicación de los conceptos "monstruo", "otredad", "horror" y "distopía". Question, Vol. 1, N.0 62, abril-junio 2019. ISSN 1669-6581 
Ahora con esas herramientas teóricas y el marco contextual que desarrollamos recientemente proseguiremos por analizar la estructura narrativa y construcción de personajes que propone John Carpenter en este filme.

La trama narra la llegada de John Nada [Roddy Piper] (4) a Los Ángeles para trabajar como obrero en un vecindario de los suburbios. A medida que los días van transcurriendo en la construcción, detecta movimientos extraños en una iglesia cercana. Cenando en la calle con otros homeless, este hombre advierte el consumo casi obsesivo de programas televisivos por parte de sus pares. Mientras se percata de esta situación, en la televisión se produce una interferencia que superpone la habitual señal televisiva con una novedosa que advierte a los humanos sobre los males de la sociedad moderna. Luego, un ataque policial desmantela el vecindario por lo que a John le llama más la atención lo que sucede dentro de la iglesia. Como de costumbre en el género de terror, la curiosidad aproxima al protagonista hacia la zona del peligro y así es como descubre que el lugar está repleto de cajas con anteojos de sol. Cuando se prueba uno, salen a la luz verdades oscuras: por un lado, la ciudad está colmada de mensajes subliminales con leyendas como "cásense y reprodúzcanse", "obedezcan", "consuman", "miren televisión" (Figura 1); y, por otro lado, gran parte de los ciudadanos presentan un aspecto cadavérico símil al de un alienígena. El conflicto de la película se introduce en el momento en que Nada es perseguido por los extraterrestres capitalistas, quienes lo vigilan por cámaras y radares. Pero, el protagonista no estará solo, sino bien acompañado por Frank Armitage y otros obreros quienes forman parte de "la resistencia", un movimiento social que fabrica anteojos que posibilitan ver la realidad que se esconde dentro de la cotidianeidad.

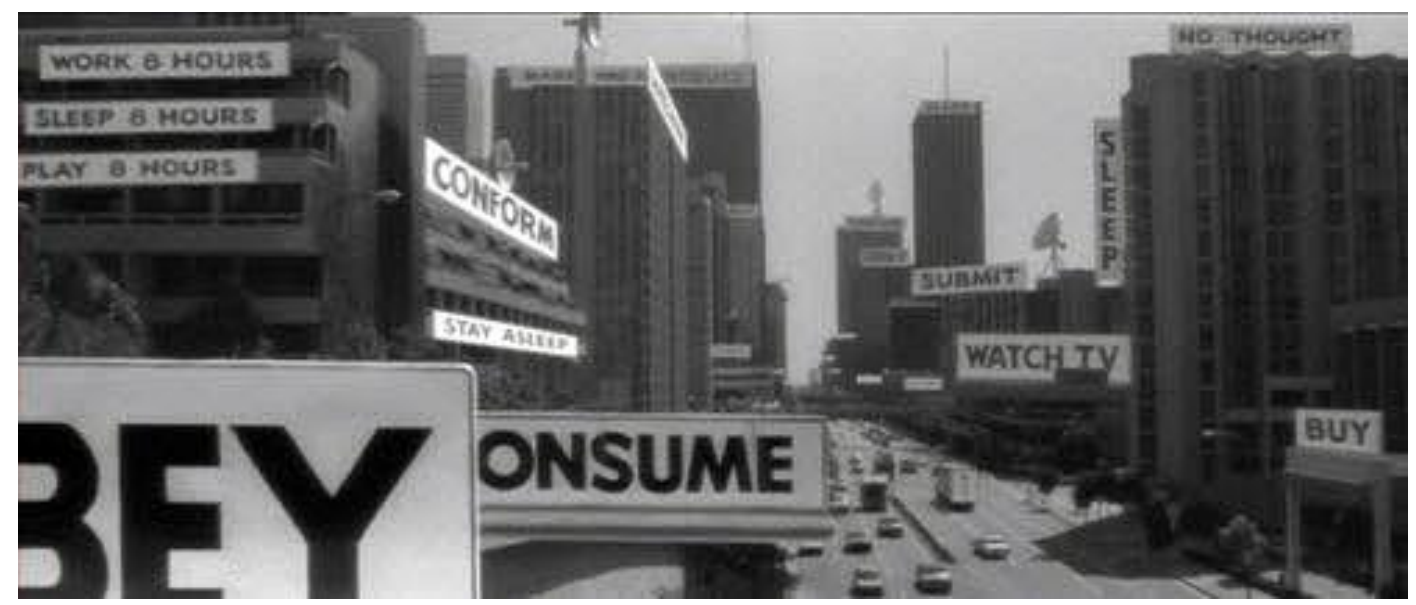

Figura 1: fotograma de They live. 
Desde aspectos netamente narrativos, la historia se reduce a ser clasificada como una distopía perteneciente al género de ciencia ficción. Una sociedad indeseable, controlada por un régimen despótico, en la que se niega el valor a pensar por voluntad propia. El agregado textual de la figura alienígena como representante del sistema autoritario inyecta una dosis humorística a la trama en tanto sátira de la sociedad estadounidense de la década del ochenta. Reagan era lo más parecido a tener a Charlton Heston o John Wayne en la Casa Blanca y Carpenter no se mostró indiferente a ello. Los agentes publicitarios, los jefes de policía, las autoridades del gobierno, entre otros, adoptan en They live un cuerpo verduzco con manchas rojas y ojos saltones; su aspecto es denso, pegajoso y desagradable; su semblante es absolutamente caricaturesco. Carpenter exagera la fisonomía cadavérica de estos extraterrestres para evidenciar el ridículo y el absurdo al que han llegado con sus ansias lucrativas.

El anhelo por asociar a los representantes políticos con una inteligencia alienígena sólo puede encontrar su respuesta en una necesidad de auto purificación o expurgación de lo naturalizado como "realidad". La lógica del fetichismo de la mercancía, que funciona como matriz estructurante de las relaciones sociales en el capitalismo, disuelve todas las relaciones interpersonales y fragmenta todas las particularidades en favor de una abstracción cada vez mayor (Lunn, 1986). El proceso de alienación comienza allí, negándole la posibilidad al individuo de concebir el mundo como propio, haciéndole sentir que la realidad que experimenta es total, ajena, le excede y que, por tanto, no puede controlarla ni transformarla. El microcosmos que diseña Carpenter presenta una realidad entendida como totalidad, en la que todo tiene que ver todo, y en la que la felicidad se consigue mediante el creciente desarrollo de las relaciones de intercambio. Sin embargo, esa totalidad es tan sólo una ilusión óptica debido a que los sujetos permanecen alienados en su constitución subjetiva. El consumo abusivo de pautas publicitarias, programas televisivos y productos se manifiesta en They live como el mecanismo efectivo que logra dinamizar y mantener el Capitalismo. De este modo, la figura terrorífica del monstruo no suscita una alteración del statu quo, sino que es su perfecta expresión.

El distanciamiento brechtiano proponía desnaturalizar las estrategias de sentido naturalizadas, con el objeto de "desalienarnos" (Jameson, 2013; Lunn, 1986). A saber, el efecto de distanciamiento podría ilustrarse de la siguiente manera: en el escenario teatral se dispone una escena familiar campesina, en la que se vibra una atmósfera de calma y quietud, de repente el ingreso de un forastero provoca una desestabilización, nos sacude y perturba, los animales vuelan y las personas gritan (Brecht, 2004). Esto significa que todo permanecía en un clima de sosiego hasta la entrada del forajido. El distanciamiento es precisamente el recorte de una imagen sumamente cotidiana en la que repentinamente sucede algo extraño que nos llama la 
atención, el tiempo se congela y nos quedamos sopesando sobre ello. El distanciamiento nos lleva a apreciar una situación que nos descoloca mientras todo acontece corrientemente. Al tomar distancia, decía Brecht, tomamos consciencia de las situaciones de explotación y dominación a las que estamos sometidos (Brecht, 2004). Y, al tomar conciencia, no podemos permanecer indiferentes. En consecuencia, adoptamos una decisión y posición política al respecto.

Por supuesto, lo expresado en el párrafo anterior no conlleva el hecho de que finalizada una puesta teatral de Brecht todos los espectadores salgan a proclamar la revolución. No estamos apuntando ideológicamente hacia esa dirección, al contrario, lo que estamos tratando de poner en palabras es que el gesto provocativo de John Carpenter de adjudicar los valores característicos del monstruo (lo abyecto socialmente) a la entidad misma del statu quo se aproxima al efecto de extrañamiento brechtiano. Ambos proponen recortar una situación tangible y familiar de nuestro día a día, le incorporan un aspecto insólito que nos toma por sorpresa (en el caso fílmico, es la presencia del otro terrorífico), con el propósito de cuestionar y reflexionar sobre la sociedad en que vivimos.

El monstruo en They live, siguiendo lo expuesto, adquiere una característica dual: por un lado, al ser una sátira del capitalismo reaganiano introduce personajes con rasgos físicos exagerados que nos invitan a reírnos del ridículo; por otro lado, su aspecto cadavérico, sus motivaciones personales y sus accionares lucrativos generan rechazo, miedo y desazón. Sin lugar a dudas, la película de Carpenter puede leerse como una distopía en tanto transcurre en una sociedad donde se niega un valor importante (el pensar por voluntad propia) a la vez que efectúa una caricaturización de la sociedad estadounidense de la década del ochenta. Es decir, cualquiera de los políticos extraterrestres que aparecen en la pantalla podría personificar al mismísimo Ronald Reagan, así como cualquiera de los homeless alienados por el consumo televisivo podrían encarnar al grueso del pueblo norteamericano.

Pero, ¿por qué hablar de ella en tanto distopía de horror?; ¿por qué englobar a esta producción dentro del género de terror?; ¿solamente porque incluye la figura de unos extraterrestres? No, no se debe a un capricho hermenéutico ni personal. Los núcleos textuales sobre los que se suele tejer la estructura narrativa de cualquier filme de terror incluyen: otredad, monstruo y represión. Empezaremos por delinear los parámetros del último concepto y volveremos a revisar las dos primeras definiciones con el objeto de advertir la reelaboración narrativa del monstruo de la que tanto hemos hecho mención hasta el momento.

Dice Robin Wood que el cine de horror opera de manera similar a los sueños en la medida en que revela temas que intentan aflorar de modos diversos pero que son aquietados y ocultados del consciente colectivo debido a sus perturbadores contenidos (2002: 30). El acto abyecto y 
trasgresor del monstruo es el que materializa "nuestro deseo por romper con las normas que nos oprimen y que nuestro condicionamiento moral nos enseña a reverenciar" (Wood, 2002: 32). De este modo, el autor logra delinear la ambivalencia que dicha figura entabla con los espectadores: por un lado, representa lo prohibido socialmente y, por otro lado, su acto liberador personifica nuestros anhelos por romper con los patrones sociales y familiares impuestos.

Ahora bien, lo señalado por Wood, en They Live no sucede. Principalmente, porque el aura abyecta del capitalismo está socialmente legitimada. En el filme de Carpenter, la señal televisiva de "la resistencia", liderada por un sacerdote de raza negra y ciego, se convierte en el órgano polifónico de un movimiento social, al cual el Estado acusará de ser un tipo de interferencia malvada que deberá ser repelido mandando policías a las calles para reprimir sus asentamientos. El advenimiento de la señal televisiva libre aparece vista como un potencial riesgo para el orden social, que debe ser eliminada (la iglesia desde donde se emite es violentamente tomada y saqueada en un raid policial) porque interfiere no solo con la programación oficial sino con el marco discursivo representativo que asigna los roles que regulan los cuerpos sociales.

Lo que hace que la señal de "la resistencia" sea tan subversiva no es meramente el modo en que quebranta la frontera emisor y receptor, advirtiendo a los ciudadanos de estar atravesando un período de somnolencia, sino el modo en que su discurso se inmiscuye dentro de los canales oficiales. Por ejemplo, mientras un hombre está mirando atentamente una publicidad donde una mujer muestra seductoramente sus piernas, inmediatamente, la señal se interrumpe con el primer plano del sacerdote diciendo: "vivimos en un estado de conciencia artificialmente inducido. La clase baja está creciendo, los derechos humanos no existen", luego, regresan las imágenes provocativas de la mujer para ser nuevamente interferidas con la frase: "en su sociedad represiva, nosotros somos cómplices involuntarios".

Entonces, retomando lo expuesto por Robin Wood sobre lo reprimido en el cine de horror, ¿quién encarna verdaderamente a lo "abyecto"? ¿El estado en su piel de invasores alienígenas o la parte más empobrecida y desprestigiada del pueblo que ansía encontrar su propia voz? A grandes rasgos, podríamos convenir sencillamente en que la señal independiente que permea tanto el espacio público como el ámbito doméstico, con sus planteos reaccionarios a la estabilidad del statu quo, representa genuinamente a lo "abyecto", es decir, a lo que se desvía de los mandatos aceptados socialmente para vivir en armonía. Su acto liberador personifica nuestros deseos de rebelarnos contra lo establecido.

Ahora bien, modifiquemos la pregunta, ¿quién adopta una figura monstruosa en la película? Los abogados, políticos, contadores, agentes de publicidad, periodistas, entre otros, aparecen 
como invasores alienígenas. El rango de estos tipos sociales genera una contradicción respecto a lo expuesto por Wood, si el autor decía que la figura del monstruo suele asociarse a lo abyecto dentro de la sociedad, entonces, ¿por qué lo que es considerado noble aparece bajo una figura vil y despreciable? ¿O es que lo abyecto siempre estuvo en manos de los mismos intérpretes, pero se lo disimulaba con la presencia de otras figuras? ¿Quién es verdaderamente el monstruo? ¿O acaso existen dos tipos de ellos: uno visible y otro invisible?

Carpenter es audaz con su propuesta narrativa. La lucha entre bien vs mal se organiza en términos inversos a los convencionales dentro del género de terror. Si lo habitual es el hombre blanco, católico y capitalista como representante del bien disputándose en contra de las fuerzas malignas del hombre comunista, de raza negra o amarilla, judío o musulmán, de clase baja, etcétera; en el caso de They live el héroe es un obrero, sin hogar, que busca combatir la moral regresiva y demoníaca del gobierno de Ronald Reagan.

Dependiendo del modo de ver, según el cual se posicione la cámara cinematográfica, la concepción del monstruo se modificará. Si nos ponemos en los pies del hombre occidental, probablemente, el capitalismo no sólo se convierta en la ideología que Estados Unidos exporta sino en el responsable de la dualidad maniquea que se genera en torno a los imaginarios del "buen patriota" y "lo extranjero". La ideología adquiere una fuerza simbólica y connotaciones del tipo puro versus no-puro y perfecto versus imperfecto. En Invasion of the body snatchers, las semillas -desde las cuales nacían los seres que invadían los cuerpos humanos- eran una alegoría de la propagación de la ideología comunista. They live presenta una temática semejante, también hay invasores de cuerpos que provienen de una galaxia muy lejana y desconocida, pero hay un intercambio de valores. El portal desde el cual se transportan los alienígenas de Carpenter -que, por cierto, es un canal de televisión- constituye una alegoría de la alienación y el peligro al que nos expone constantemente el sistema capitalista que habitamos día a día (Figura 2). 


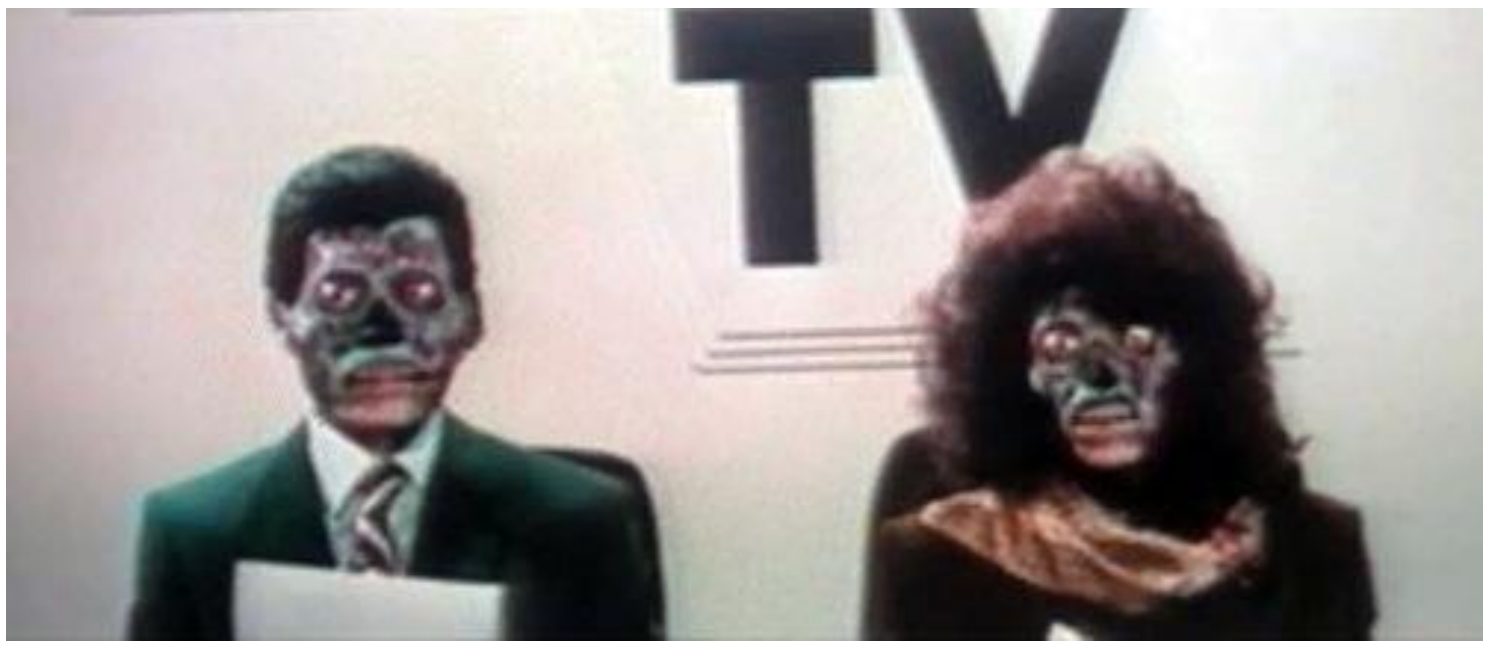

Figura 1: fotograma de They live.

Sea como fuera, hay dos monstruos en They live así como existen dos señales televisivas que representan la batalla entre el bien y el mal. Por un lado, una otredad visible, perteneciente al mundo real cotidiano, representada por seres marginales, homeless, desempleados, obreros y activistas revolucionarios. Dichas figuras encuentran su modo de expresión mediante una señal de televisión independiente y el movimiento social "la resistencia", liderado por un sacerdote de raza negra y ciego. Si bien no presentan alteraciones ni deformidades físicas, así como no provienen de mundos paralelos, su sola presencia significa una amenaza para la mantención del orden social. Al poseer características que se salen de la norma legitimada devienen seres abyectos $y$, por tanto, en monstruos para el resto de la sociedad. Por estas razones, serán perseguidos, encarcelados, torturados y asesinados en nombre del bienestar y la paz.

Por otro lado, se observa una otredad invisible, perteneciente al mundo real auténtico, que sólo se puede alcanzar a ver por medio de unos anteojos de sol que reparte el movimiento de "la resistencia". Dicha otredad está conformada por alienígenas que invaden el cuerpo de políticos, agentes de publicidad, burgueses y abogados (Figura 3). Para poder difundir su ideología y ansias de dominación envían señales hipnóticas mediante la publicidad y todas las señales televisivas existentes en la faz de la tierra. Son la auténtica materialización del statu quo. Nadie los persigue y nadie sospecha de ellos. Nadie sabe que están vivos. La excepción de ese conocimiento lo posee "la resistencia" que sí intentará hacer todo lo posible por aniquilarlos y salvar a la humanidad entera. 


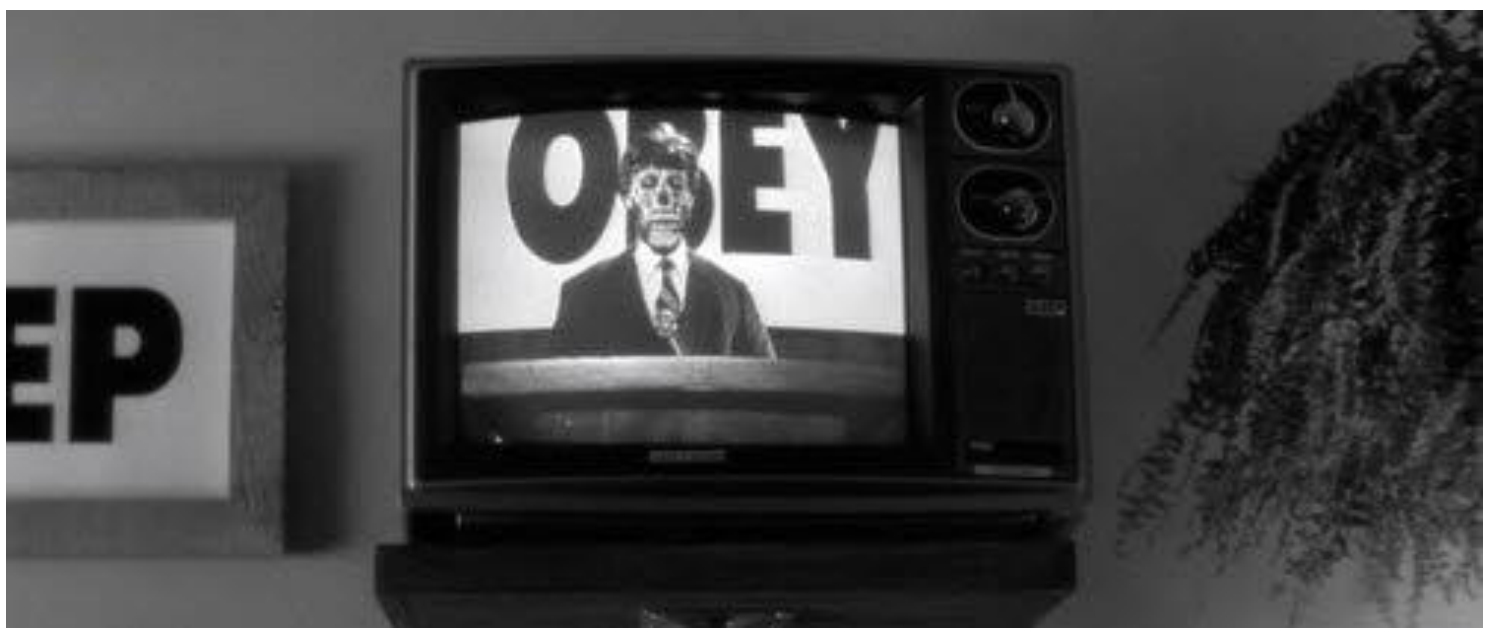

Figura 3: fotograma de They live.

El conflicto entre el bien y el mal que propone Carpenter no podría estar más sustentado en la lucha de clases del pensamiento marxista. La guerra casi sin sentido de todos contra todos queda evidenciada en esa dualidad maniquea. Sin embargo, el tratamiento narrativo que desarrolla Carpenter se vehiculiza con eficacia hacia el desmantelamiento del statu quo, otorgando la posibilidad de construir una nueva idea sobre la moral y la política. La propuesta se desvía de la tradición del género de terror que dispone, luego de la alteración del orden social, un retorno al statu quo. They live va en detrimento de esa fórmula harto conocida, al mostrar sujetos que aceptan inconscientemente el estado normal de cosas para, finalmente, derrotar las normas y mandatos hegemónicos impuestos.

\section{Ver o no ver. El dilema del héroe}

"Ver" implica un modo de mirar el mundo que nos rodea. Para John Berger (2005), lo visible no existe en ninguna parte, es simplemente un conjunto de imágenes que el ojo crea al mirar. La realidad es visible en tanto es percibida. Lo que sabemos o lo que creemos saber afecta al modo en que vemos las cosas. Mirar es un acto voluntario, vemos lo que está a nuestro alcance y la relación que mantenemos con los objetos de mundo. John Berger establecía:

lo visible es un invento. Sin duda, uno de los inventos más formidables de los humanos. La cámara de televisión fue un gran hito en la historia de este deseo. La televisión nos permitió ver imágenes nunca antes vistas. Y empezamos a creer que la cámara, con su zoom y su 
macro, con sus planos generales y sus primerísimos planos, era el instrumento que realmente nos brindaba la verdad sobre lo real (2005: 7).

Una imagen es una visión y un invento. Una imagen es pura apariencia. Toda imagen encarna un modo de ver. Lo que vemos está condicionado por una serie de hipótesis y juicios aprendidos acerca de nuestro mundo cotidiano. Suposiciones que refieren a: la verdad, la civilización, los modos de conducta, etcétera. Un desvío del eje desde el cual permanecen estacionarios esos imaginarios genera un extrañamiento y desconcierto. Si nos dicen que la realidad no es efectivamente aquella que creemos conocer, entonces, nos perturbamos y desorientamos. Por eso, es que "ver" implica un modo particular de mirar el mundo. Y ver sin artificios, maquillajes o veladuras, por supuesto, conlleva aceptar una serie de nuevos juicios que probablemente no siempre estemos dispuestos a admitir.

En la película de Carpenter, el modo de mirar la verdad cotidiana y la verdad real supone un pasaje virtual mediante un elemento peculiar: lentes. Sin embargo, no se trata de cualquier tipo de lentes, al principio, se utilizan anteojos de sol, es decir, gafas coloreadas u oscurecidas que protegen a los ojos de la luz directa y molesta que emiten los rayos ultravioletas. El modo de mirar que adopta quien los usa es de una visión periférica en blanco y negro, donde lo que escuchamos permanece igual, pero lo que cambian son las imágenes. En este sentido, la acción de colocarse y quitarse los anteojos indica el traspaso de una dimensión a otra. Instantáneamente, la imagen de la realidad pasa de ser colorida, estimulante, atractiva, con avisos publicitarios en las islas del Caribe a manifestar una realidad en blanco y negro, deslucida, críptica y nefasta donde la publicidad paradisíaca en verdad dice "cásate y reprodúcete".

Los anteojos de sol no sólo repelen la luz invasiva y dañina proveniente del sol, sino que también protegen del daño que la realidad artificial produce. De hecho, cada vez que uno de los personajes permanezca con los lentes puestos por una cantidad de tiempo extensiva comenzarán a sentir náuseas, mareos y dolores de cabeza. Los efectos de contemplar una realidad no ficcionalizada $y$, por tanto, real generan una serie de cambios físicos y cognoscitivos. El mundo aparenta ser el mismo más no lo es. Aceptar un modo de ver que admita la disposición real del estado de cosas implica un duelo, una anomalía física, un despojarse del pasado para fluir en un presente incierto.

Sin embargo, en They live no todos los personajes aceptan el desafío de ponerse los anteojos para poder mirar la situación de explotación alienígena a la que están expuestos. En la escena más antológica de la película, John Nada intenta convencer a Frank Armitage de que se ponga los anteojos y vea realmente lo que sucede. Pero Frank se niega. Nada insiste y Frank vuelve a 
rehusarse. Nada no se da por rendido y lo que prosigue es una pelea de más de seis minutos en un callejón, hasta que Nada logra su propósito (Figura 4). La extensa duración de la escena se debe a la resistencia que impone Armitage por adoptar ese modo de ver epifánico. Como mencionamos líneas más arriba, aceptar que lo que vemos pertenece al orden de la ficción conlleva un duelo, una experiencia dolorosa, y debemos forzarnos a nosotros mismos para poder atravesar el proceso.

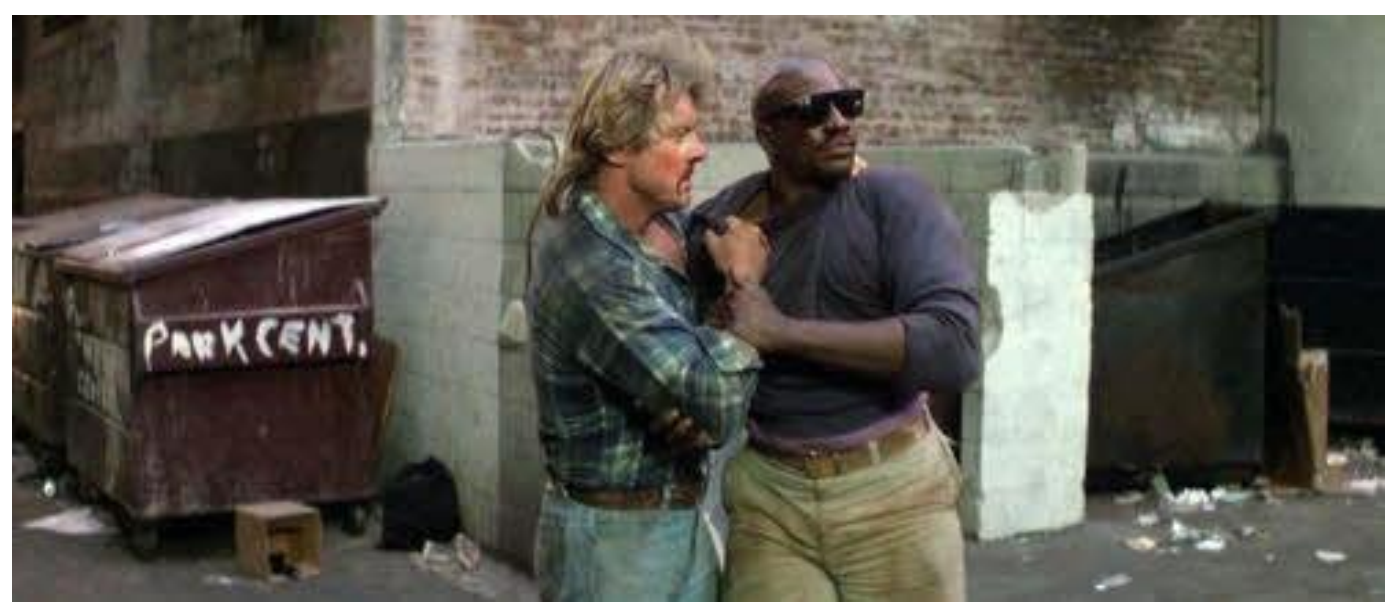

Figura 4: fotograma de They live.

La escena dura aproximadamente unos ocho minutos y, hasta por momentos, puede parecer irracional. ¿Por qué se resiste tanto este hombre a colocarse los anteojos? ¿Qué es lo que tanto teme? Pareciera como si él, en efecto, ya conociera de antemano la ficcionalización y artificialidad ética en la que vive día a día. Al mismo tiempo, pareciera que él ya supiera que en cuanto acceda a ese modo de ver, todas sus ilusiones y proyectos sustentados en el futuro se quebrarán. La libertad de estos personajes pende de un hilo. Los actos voluntarios y el libre pensamiento sólo van de la mano de aceptar esa realidad monstruosa que enseña un par de anteojos de sol. Sin embargo, luego de reconocerla, la experiencia que atravesarán será sumamente dolorosa. John Nada, a su manera, irá comprendiendo que su apellido es sintomático: no tiene trabajo, ni solvencia económica, tampoco posee un hogar donde residir; su presencia nada significa para los poderosos. Dentro del sistema capitalista, Nada es un número más dentro de los millones de habitantes del planeta tierra. Es una auténtica nada. Reconocer y atravesar el proceso, evidentemente, es muy doloroso. 


\section{Conclusiones}

La película de John Carpenter constituye un caso paradigmático dentro del cine de terror estadounidense. Las formas convencionales del monstruo son modificadas en virtud de exhibir una figura cotidiana y tangible, que representa la materialización del statu quo. A diferencia de producciones cinematográficas precedentes, la otredad ya no constituye un peligro para la mantención del orden social, sino que es su auténtica expresión. Retomando elementos distópicos provenientes del género de ciencia ficción, Carpenter desarrolla en They live una caricaturización de la sociedad norteamericana de la década del ochenta. Personificando a los políticos y autoridades como alienígenas, también, realiza una crítica social al gobierno regresivo y conservador de Ronald Reagan. La ideología de este gobierno se había basado en la permanente difusión de imágenes, ya sea por medio de las publicidades o canales de televisión, de los eventos y discursos presidenciales. Mientras gran parte del pueblo empobrecía y quedaba desprovisto de solvento económico, se percibía un acrecentamiento de las apariciones de Reagan en televisión. La decisión estética de Carpenter de elegir a un estudio televisivo como portal que une a dos galaxias distintas tiene su efecto narrativo en tanto alegoría de la alienación que suscitaba el desarrollo del conservadurismo del gobierno de Reagan. They live constituye una distopía de horror: por un lado, es una distopía, por ofrecer una sátira de la sociedad estadounidense de los ochenta; y, por otro lado, su contenido narrativo es de "horror" por incluir una dimensión del mundo desconocida que sólo se conoce a raíz de un par de anteojos de sol. El horror lo genera el contenido narrativo de atravesar el proceso de duelo: aceptar que el mundo paradisíaco que vivimos no es tal, y que estamos inmersos en un sistema de dominación perverso, administrado por un conjunto de alienígenas.

Notas

(1) Esta representación convencional suele propagarse en otros géneros narrativos con bastante popularidad. Basta con recordar la caracterización de "bloque de hierro" que acompaña a Iván Drago en Rocky IV (Sylvester Stallone, 1985).

(2) Película basada en la novela homónima de Ray Bradbury publicada en 1953.

(3) El cuento fue publicado en la revista The Magazine of Fantasy \& Science Fiction en 1963. En 1986, fue adaptado al cómic bajo el título 'Nada', cuyo guion fue escrito por Ray Nelson e ilustrado por Bill Wray. La edición gráfica fue la que cautivó a John Carpenter para escribir y dirigir la película They live.

(4) Luchador de catch que trabajó en algunas producciones de bajo presupuesto y en programas de televisión antes de encabezar They live, John Carpenter lo eligió porque, al igual que Nada, Piper había vivido en las calles antes de triunfar dando golpes arriba del cuadrilátero (Orta, 2012: 82). 
(5) Luego, llegando al final de la película, la tecnología del movimiento "la resistencia" se perfecciona y comienzan a utilizarse lentes de contacto.

\section{Bibliografía}

Altman, R. (1999). Los géneros cinematográficos. Buenos Aires: Paidós.

Brecht, B. (2004). Escritos sobre teatro. Barcelona: Alba Editorial.

Berger, J. (2005). Modos de ver. Barcelona: Editorial Gustavo Gili.

Capanna, P. (1992). El mundo de la ciencia ficción. Buenos Aires: Ediciones Letra Buena.

Carpenter, J. (director) (1988). They live! (¡Están vivos!) [cinta cinematográfica]. USA: Alive Films.

Cuéllar Barona, M. (2008). La figura del monstruo en el cine de horror. Revista CS, 2, 227-246. doi: https://doi.org/10.18046/recs.i2.419

Guerrero, E. (1993). Framing Blackness. The African American Image in Film. Philadelphia: Temple UP.

Jameson, F. (2013). Brecht y el método. Buenos Aires: Manantial.

Jenkins, P. (2012). Breve historia de Estados Unidos. Madrid: Alianza Editorial.

Marzal, J. J. (1996). Melodrama y géneros cinematográficos. Valencia: Ediciones Episteme.

La Torre, J.M. (1994). Años 50, años de paranoia. Un género sin lenguaje propio. Nosferatu, revista de cine, 14, 4-13.

Lunn, E. (1986). Marxismo y modernismo. México: Fondo de Cultura Económica.

Orta, M. (2012). ¡Encerrados toda la noche! El cine de John Carpenter. Buenos Aires: Cuarto Menguante.

Wood, R. (2002). The American Nightmare: Horror in the 70's. En Jancovich, M. (ed.). Horror. The Film Reader. Londres: Routledge.

Viejo, B. (2002). Jim Jarmusch y los sueños justos. España: Ediciones JC. 